\title{
Cold Physical Plasma Selectively Elicits Apoptosis in Murine Pancreatic Cancer Cells In Vitro and In Ovo
}

\author{
KIM ROUVEN LIEDTKE ${ }^{1}$, STEPHAN DIEDRICH ${ }^{1}$, ONUR PATI $^{1}$, ERIC FREUND ${ }^{1}$, ROBERT FLIEGER ${ }^{1}$, \\ CLAUS DIETER HEIDECKE ${ }^{1}$, LARS IVO PARTECKE $^{1 *}$ and SANDER BEKESCHUS ${ }^{2 *}$ \\ ${ }^{1}$ Department of General, Visceral, Thoracic and Vascular Surgery, \\ University Medical Center Greifswald, Greifswald, Germany; \\ ${ }^{2}$ ZIK plasmatis, Leibniz Institute for Plasma Science and Technology (INP Greifswald), Greifswald, Germany
}

\begin{abstract}
Background/Aim: Poor prognosis of pancreatic cancer has remained almost unchanged in recent years. Cold physical plasma was suggested as an innovative anticancer strategy, but its selective killing activity of malignant over nonmalignant cells has only partially been explored. The present study aimed at exploring the effect of cold physical plasma on cellular viability. Materials and Methods: Induction of cell death and apoptosis by cold physical plasma was investigated in murine PDA6606 pancreatic cancer cells and primary murine fibroblasts in vitro ( $2 D$ and $3 D$ cultures) and in ovo. Results: Plasma increased apoptosis in PDA6606 to a significantly higher extent compared to fibroblasts. Antioxidants abrogated these effects, suggesting a prime role of reactive oxygen species in plasma-induced apoptosis. Plasma increased apoptosis of 3D PDA6606 multicellular spheres grown in vitro and in ovo, to significantly higher rates compared to that of fibroblasts, with minimum in ovo inflammation or necrosis observed by hematoxylin and eosin staining $(H \& E)$. Conclusion: These data support the future intra-operative application of cold physical plasma for the treatment of microscopic residual tumor tissue after surgical resection.
\end{abstract}

Annually, pancreatic cancer causes over 330,000 deaths worldwide (1). Its incidence is rising in both genders, counteracting a global trend in cancer epidemiology (2). The absence of specific early symptoms leads to delayed diagnosis. At late stages, only $20-30 \%$ of the patients present

*These Authors contributed equally to this study.

Correspondence to: Kim Rouven Liedtke, MD, University Medicine Greifswald, Department of General, Visceral, Thoracic and Vascular Surgery, Ferdinand-Sauerbruch-Straße, 17475 Greifswald, Germany. Tel: +49 3834866001, Fax: +49 3834866071, e-mail:kim.liedtke@uni-greifswald.de

Key Words: kINPen MED, plasma medicine, reactive oxygen species, TUM-CAM assay. with resectable tumors (3). Both aggressive local growth and early metastatic dissemination often impede curative therapy and result in a high rate of surgical R1-resections. Micrometastasis in these margins are the major cause for tumor relapse in pancreatic cancer patients (4). This results in median survival of only 18 months (5), calling for new therapeutic strategies in the treatment of pancreatic cancer.

Cold physical plasma is a partially ionized gas expelling a variety of reactive oxygen species (ROS) (6-8). This cocktail of plasma-derived ROS was shown to display considerable toxicity towards tumors in different kinds of cancers in vitro, including for example melanoma (9-11), glioblastoma (12-14), leukemia (15-17), ovarian cancer (18-20), prostate cancer (2123 ), and colon cancer (24-26). Several groups have determined profound anticancer activity of cold physical plasmas in tumor animal models (27-29). Successful application of the atmospheric pressure argon plasma jet kINPen MED in cancer patients has been reported (30-32). Importantly, this plasma device was tested negative for genotoxic effects using appropriate model systems (33-35). Yet, it is unclear to what extent the kINPen MED plasma jet provides selective toxicity in malignant versus non-malignant cells.

To this end, the toxicity of cold physical in murine PDA6606 pancreatic cancer cells was compared to that in non-malignant, primary murine fibroblasts. Using cells grown in $2 \mathrm{D}$ and $3 \mathrm{D}$ in vitro, and in $3 \mathrm{D}$ on fertilized eggs (in ovo) according to the TUM-CAM assay (36), a selective and thus tumor-toxic effect of cold physical plasmas towards pancreatic cancer cells was clearly identified in these model systems. Our results suggest a potential implementation of cold physical plasma, maybe, as adjuvant treatment in the therapy of pancreatic cancer.

\section{Materials and Methods}

Cell line and culture. 6606PDA cells (a kind gift from David Tuveson, John Hopkins University, Philadelphia, USA) have been isolated from a pancreatic adenocarcinoma of a transgenic C57BL/6 Kras ${ }^{\mathrm{D} 12 \mathrm{G}}$ knock-in mouse (37). Primary, non-immortalized murine 
fibroblasts were isolated from C57BL/6 embryos, as previoulsy described (38). Both cell entities were maintained in Dulbecco's Modified Eagle Medium (DMEM) supplemented with $10 \%$ fetal bovine serum, $100 \mathrm{U} / \mathrm{ml}$ of penicillin, and $100 \mu \mathrm{g} / \mathrm{ml}$ of streptomycin. Cells were subcultured twice a week for up to 10 passages. Cell culture reagents were obtained from Gibco (Invitrogen; Carlsbad, CA, USA). Cell cultures were kept pathogenfree in a humidified incubator at $37{ }^{\circ} \mathrm{C}$ in an atmosphere of $5 \% \mathrm{CO}_{2}$, and were regularly tested negative for mycoplasma contamination.

Cold physical plasma. Cold physical plasma (Figure 1) was generated by the atmospheric pressure argon plasma jet kINPen MED (neoplas tools; Greifswald, Germany). It has received accreditation as medical device class IIa (39). Embedded in the hand-held unit and shielded by a dielectric capillary, the argon gas (purity greater $99.999 \%$ ) was excited by a rod-like electrode using three standard liters of argon gas flow. Application was carried out from a distance of $5 \mathrm{~mm}$ of the plasma tip from the tissue surface. As sham treatment, argon gas flow alone (without electrical excitation or plasma generation) was used in some experiments.

Metabolic activity in vitro. For the assessment of metabolic activity in vitro, $2 \times 10^{3}$ cells were seeded into each well of a 96-well plate. After overnight attachment, supernatants were discarded and fresh cell culture medium was added. Subsequently, the argon plasma jet was directly hovered over the center of each well for the indicated time length. In some experiments, the culture medium was supplemented with the antioxidant $\mathrm{N}$-acetylcysteine (NAC; Sigma; St. Louis, MO, USA). Following treatment, cells were returned to the incubator. After $24 \mathrm{~h}$ cells were washed, incubated with resazurin (Alfa Aesar; Ward Hill, MA, USA) for $3 \mathrm{~h}$, and its transformation to resorufin was determined by fluorescence measurement in a microplate reader (Tecan; Männedorf, Switzerland) at $\lambda_{\mathrm{ex}}=535 \mathrm{~nm}$ and $\lambda_{\mathrm{em}}=590 \mathrm{~nm}$.

Detection of cell death and apoptosis of $3 D$ multicellular spheres in vitro. To grow three-dimensional multicellular spheres, $5 \times 10^{5}$ PDA6606 cells or fibroblasts were added into cell culture inserts (5 $\mathrm{mm}$ plastic templates, self-made) in 12-well plates. After overnight incubation, inserts were removed and supernatant was exchanged with $500 \mu \mathrm{l}$ of fresh medium leaving only a thin liquid film on the cells. Then, plasma treatment was carried out for $20 \mathrm{sec}$. The control group was exposed for $20 \mathrm{sec}$ to argon gas only. After treatment, cells received $2 \mathrm{ml}$ of fresh medium, and the dish was returned to the cell culture incubator. Cell death and apoptosis analyses were performed using allophycocyanin-labeled annexin $\mathrm{V}$ and propidium iodide (both BD Pharmingen; Heidelberg, Germany) at 1, 24, and 48 $\mathrm{h}$ following plasma treatment. Briefly, cells were detached with Trypsin/EDTA, washed, and incubated in annexin V binding buffer (BioLegend; London, UK) containing annexin $\mathrm{V}$ and propidium iodide. Cells were washed, fluorescent signals were acquired by flow cytometry (LSR II; Becton Dickinson, Heidelberg), and data were analyzed using FlowJo software (TreeStar; Ashland, OR, USA).

In ovo tumor-chorio-allantoic membrane (TUM CAM) fertilized chicken embryo model. Pathogen-free fertilized eggs were obtained from VALO Biomedia (Osterholz-Scharmbeck, Germany). After delivery, eggs were incubated for 6 days at $37^{\circ} \mathrm{C}$ and $65 \%$ relative humidity in a motorized incubator (Thermo-De-Luxe 250; J. Hemel Brutgeräte; Verl, Germany). On day 6, a small hole $(<1 \mathrm{~mm})$ was

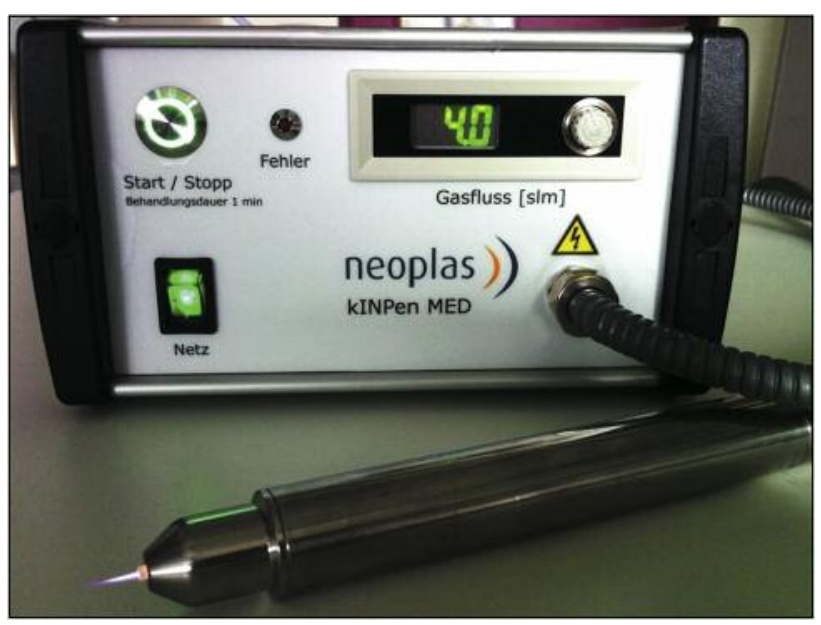

Figure 1. The atmospheric pressure argon plasma jet kINPen MED. The jet excites a flux of argon gas at the tip of a rod-like electrode in the inner part of the head (smaller part on the left of the pen-like housing at the bottom of the image). The excited argon molecules are driven to the ambient air, reacting with room air oxygen and nitrogen, to generate a mixture of reactive oxygen and nitrogen species (violet plasma effluent at the lower left of the image).

punched into the pointed end of the eggs using a cannula (20G) to generate an air cell. The hole was then closed with a self-adhesive tape, and eggs were incubated for two additional days. On day 8, eggs were carefully opened at the pointed end and the surface of the chorio-allantoic membrane (CAM) was slightly roughened using a $5 \times 5 \mathrm{~mm}$ filter paper (TISSUE-TEK II; Vogel, Germany) saturated with diethyl ether. Onto this area, a sterile silicone ring was placed (5 mm inner and $6 \mathrm{~mm}$ outer diameter). Thereafter, $2 \times 10^{6}$ PDA6606 cells or fibroblasts were resuspended in $10 \mu \mathrm{l}$ BD Matrigel (BD Biosciences, USA) and $5 \mu$ DMEM. This suspension was carefully filled into the silicone ring. Eggs were covered with Tegaderm (3M Healthcare; Neuss, Germany) to avoid evaporation and were returned to the incubator. On day 12, multicellular spheres were exposed to plasma in ovo, while controls received argon gas only. Eggs were placed back into the incubator for another $48 \mathrm{~h}$ (Figure 2).

Immunofluorescence and histology. On day 14, multicellular spheres were excised, stored overnight in formalin, and embedded in paraffin. Thin sections $(2 \mu \mathrm{m})$ were cut vertically and mounted on glass slides. Following deparaffinization with xylene and ethanol (100\%), sections were stained with H\&E according to standard protocols. To quantify apoptotic cells, TUNEL assay (CALBIOCHEM, Merck, Darmstadt, Germany) was performed according to manufacturer's specifications. Using fluorescence microscopy (Keyence; Neu-Isenburg, Germany) the ratio of TUNEL-positive (DAPI-positive) cells was determined.

Statistical analysis. Graphics and statistical analyses were performed using prism 7.04 (GraphPad Software, USA). In vitro experiments were repeated at least three independent times. Statistical comparison was performed using multiple $t$-tests with Holm-Sidak post-testing correcting for multiple comparisons. 


\section{Delivery, incubation (1h rotation, $2 \mathrm{~h}$ repose) \\ Hole-making stop rotation}

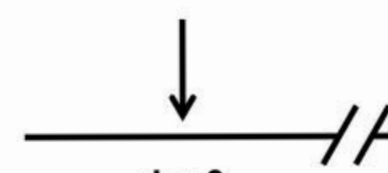

day 0

day 6
Tumor implantation

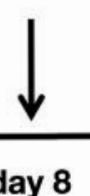

day 8
Plasma-treatment

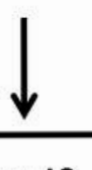

day 12

Tumor explantation

histology

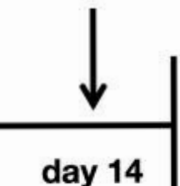

Figure 2. Experimental design of TUM-CAM in ovo assay. After delivery, eggs were stored in the incubator with intermittent rotation. On day 6, small holes were punched in the eggshell for creating an air pocket. On day 8, PDA6606 murine pancreatic cancer cells or murine primary fibroblasts were implanted, and chicken embryos were again incubated. On day 12, cold physical plasma treatment was performed. On day 14, PDA6606 or fibroblasts spheres were removed and analyzed via immunofluorescence for apoptosis and histologically.

Significance levels were indicated as follows: $* \alpha=0.05, * * \alpha=0.01$, and $* * * \alpha=0.001$. Data are shown as individual data points and mean, or mean \pm standard error.

\section{Results}

Cold physical plasma selectively inactivated murine pancreatic cancer cells over murine fibroblasts via release of reactive oxygen species in vitro. Cold physical plasma is a partially ionized gas expelling various reactive oxygen species (ROS) that have been shown to be toxic to tumor cells. To address the selectivity of this novel treatment regimen, the toxicity of cold plasma was examined using murine PDA6606 pancreatic cancer cells and murine primary fibroblasts. To this end, the metabolic activity of cells was assessed $24 \mathrm{~h}$ after plasma treatment of 2D monolayer cell cultures in vitro. Compared to mock-treated argon gas controls, plasma treatment significantly reduced metabolic activity of pancreatic cancer cells but not that of fibroblasts (Figure 3A). Supplementation with the ROS-scavenging antioxidant Nacetylcysteine (NAC) reversed plasma-mediated toxicity in a concentration-dependent manner. At 2 and $4 \mathrm{mmol} / 1$ of NAC, exposure to plasma significantly decreased the metabolic activity of pancreatic cancer cells compared to that of murine fibroblasts (Figure 3A). At higher NAC concentrations, there was still a differential response of these cell types. Interestingly, the lowest NAC concentrations nearly abolished plasma effects in fibroblasts, whereas pancreatic cancer cells were only partially protected. This difference might offer a therapeutic window for minimizing potential harmful effects of plasma treatment in patients by adding small amount of scavenger. Altogether, these results indicate that plasma treatment is more toxic to pancreatic cancer cells than fibroblasts in the presence of NAC.

Cold physical plasma selectively induced apoptosis and terminal cell death in murine pancreatic cancer cells over murine fibroblasts in vitro. To investigate cell death in a more relevant three-dimensional culture system, tumor or fibroblasts were grown in tissue-like spheres in vitro, before being subjected to plasma treatment. Spheres were dissociated and the total percentage of dead and apoptotic cells was evaluated by flow cytometry. There was a significant increase of apoptotic cells in plasma-treated PDA6606 pancreatic cancer cells over primary murine fibroblasts assayed $24 \mathrm{~h}$ and $48 \mathrm{~h}$ after plasma treatment (Figure 3B). Notably, apoptotic rates in fibroblasts decreased between $24 \mathrm{~h}$ and $48 \mathrm{~h}$ whereas they were increasing in pancreatic cancer cells. This suggests stronger counterregulation mechanisms in fibroblasts but not in tumor cells. The significantly elevated percentage of apoptotic fibroblasts over cancer cells at $1 \mathrm{~h}$ may be explained by a higher percentage of dead fibroblasts in the controls. Since fibroblasts were isolated from primary murine tissue, they are more prone to cell culture-induced toxicity. By contrast, quantifying the percentage of terminally dead (propidium iodide $^{+}$) cells at $1 \mathrm{~h}$, PDA6606 pancreatic cancer cells were found to be significantly more vulnerable (Figure 3C) compared to murine fibroblasts. This finding became more pronounced with increasing incubation times of $24 \mathrm{~h}$ or 48 $\mathrm{h}$ post plasma treatment.

Cold physical plasma elicited apoptosis preferentially in spheres grown from murine pancreatic cancer cells over that of primary fibroblasts. Plasma treatment selectively induced apoptosis of murine pancreatic cells over fibroblasts in a ROS-dependent manner in 2D monolayers and 3D sphere cultures in vitro. However, even $3 \mathrm{D}$ in vitro tissue cultures lack parts of the tumor microenvironment in living hosts. To address this complexity while minimizing the need for animal experiments (in vivo), the TUM-CAM assay has been developed which utilizes fertilized chicken embryos harboring a pre-mature central nervous system up to day 15 (36). Accordingly, we implanted either murine PDA6606 pancreatic cancer cells or murine primary fibroblasts onto 
chorio-allantoic membranes of eggs (in ovo) and assayed the tissue response following exposure to cold physical plasma. Counterstaining of nuclei with DAPI and DNA fragments of apoptotic cells with the TUNEL assay revealed overall similar spontaneous apoptosis for either of the cell types in the argon gas mock treatment group (Figure 4). By contrast, there was a notable increase in apoptosis in PDA6606 murine pancreatic cancer cells over primary murine fibroblasts following plasma treatment for $10 \mathrm{sec}$ or $30 \mathrm{sec}$. Quantifying the percentage of apoptotic cells in both cell types, fibroblasts were significantly less affected by plasma treatment compared to cancer cells. Consistent with the in vitro observations, the in ovo results suggested fibroblasts to be significantly more resistant to cold physical plasmainduced apoptosis than pancreatic tumor cells. This was confirmed by H\&E staining of sections of in ovo spheres exposed either to mock treatment with argon gas or cold physical plasma. Fibroblast spheres did not show any morphological changes following $30 \mathrm{sec}$ of plasma treatment (Figure 5A and 5B). However, plasma treatment of PDA6606 cells in ovo elicited morphological signs of apoptotic cell death such as cellular shrinking, condensed and bright eosinophilic cytoplasm, and pycnotic dark small nuclei due to chromatin condensation (Figure 5C and 5D). Nevertheless, the rest of cells retained their malignant phenotype with some showing mitotic activity. In general, no inflammatory reaction or large necrotic areas were noted following plasma treatment.

\section{Discussion}

Notwithstanding general translational and clinical progress in cancer treatment, prognosis for patients suffering from pancreatic cancer remains very poor. In search of possible add-on treatment procedures, the toxicity and selectivity of cold physical plasma in murine pancreatic cancer cells was investigated and compared to non-malignant, primary fibroblasts.

Cold physical plasma treatment reduced metabolic activity and induced apoptosis, as well as early terminal cell death in pancreatic cancer cells. This is in line with other findings reporting on pro-apoptotic effects of plasma treatment in human or mouse cancer cell lines (40-45). We have also observed apoptosis in COLO-357 tumor spheres grown in ovo (TUM-CAM) following exposure to an argon plasma jet earlier (36). It is subject of ongoing research which main active components in plasmas mediate such biological response. In principle, cold physical plasmas are multicomponent systems releasing mild heat, electrons and ions, electric fields, UV-radiation, and reactive oxygen and nitrogen species (ROS/RNS) (46). In 2D cell culture systems, adherent cells are covered by cell culture medium to protect them from drying out. Plasma components need to
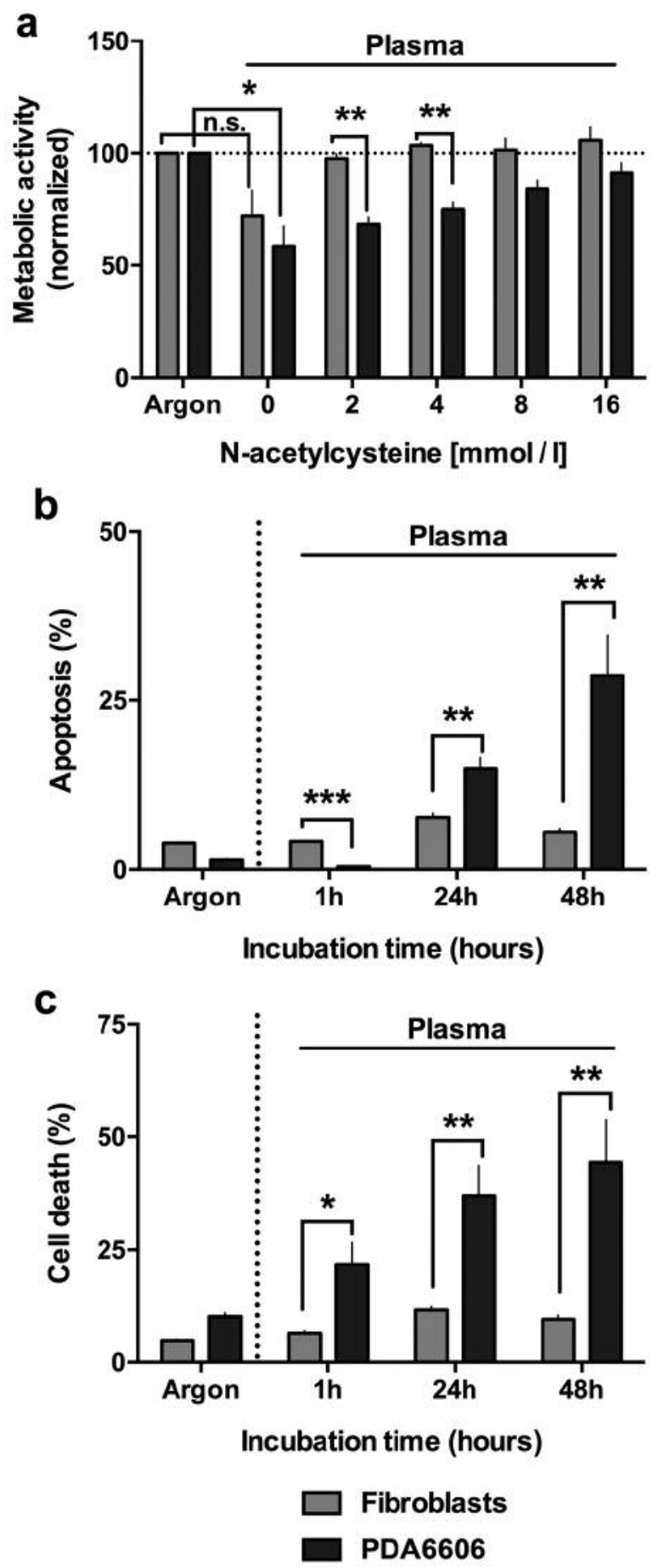

Figure 3. Cold physical plasma reduced metabolic activity and induced apoptosis in pancreatic cancer cells grown in vitro as $2 D$ monolayers or 3D multicellular spheres. (A) Metabolic activity of PDA6606 murine pancreatic cancer cells and fibroblasts $24 \mathrm{~h}$ post exposure to cold physical plasma $(60 \mathrm{sec})$ in the presence of ROS-scavenger $N$-acetylcysteine (NAC); $(B, C)$ Percentage of annexin $V+$ apoptotic $(B)$ and propidium iodide+ terminally dead cells $(C)$ in argon gas control and plasma-treated (20 sec) PDA6606 murine pancreatic cancer cells and murine primary fibroblasts grown in $3 D$ multicellular spheres in vitro. Data show mean + standard error of 4-5 independent experiments. 
a
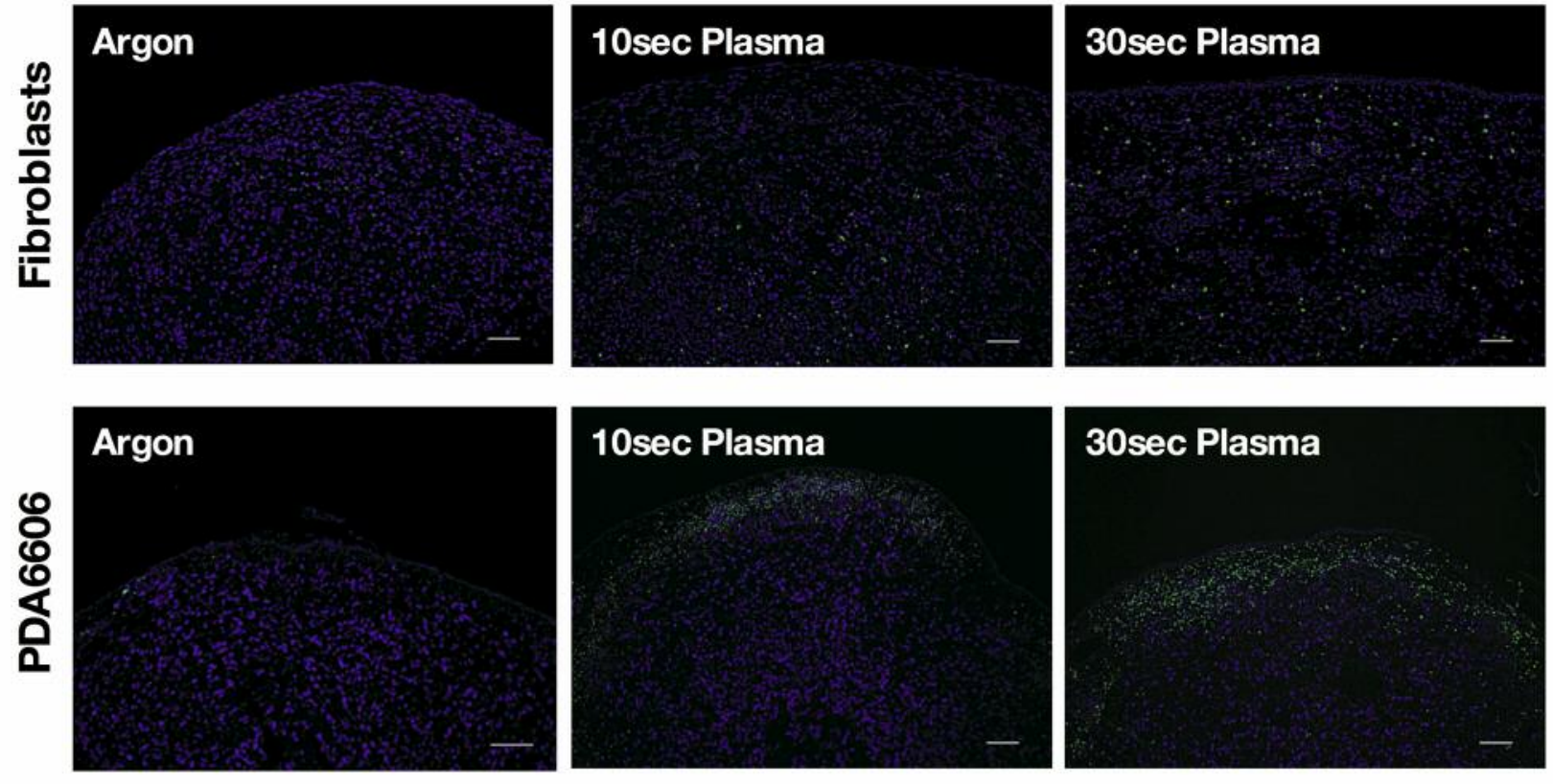

b

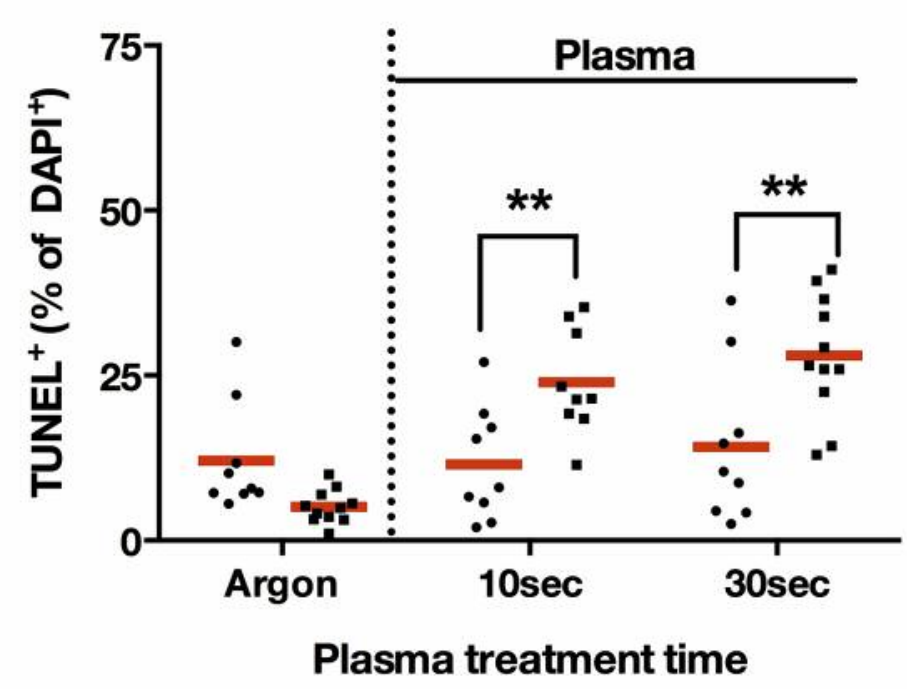

- Fibroblasts

- PDA6606

Figure 4. Exposure to cold physical plasma elicited apoptosis preferentially in spheres grown in ovo from murine pancreatic cancer cells over that from primary fibroblasts. (A) Representative images of sphere sections stained for nuclei (DAPI, blue) and apoptotic cells (TUNEL, green); (B) ratio of TUNEL+ over DAPI+ cells among all treatment groups. Data are from 9-11 tissue sections per group; scale bars represent 50 um, ** $<0.01$.

travel through this liquid in order to be active. Damaging, long-lived UV radiation (UV-C) only penetrates in the order of $100 \mathrm{~nm} \mathrm{(47),} \mathrm{eliminating} \mathrm{this} \mathrm{possible} \mathrm{effector.}$ Temperature measurements of plasma-treated liquids have ruled out this mode of action. Electrons and ions quickly deteriorate at the plasma gas-liquid interphase (48). Electric fields are negligible with the atmospheric pressure argon plasma jet kINPen MED used in this study (49). This leaves ROS/RNS as main driver of plasma effects in in vitro cultures. Many kinds of reactive species were so far identified in plasma-treated liquids (50) including superoxide, singlet delta oxygen, peroxynitrite, and hydrogen peroxide (51-54). Disassembling the plasma-derived redox chemistry was out of the scope of the current study, but 

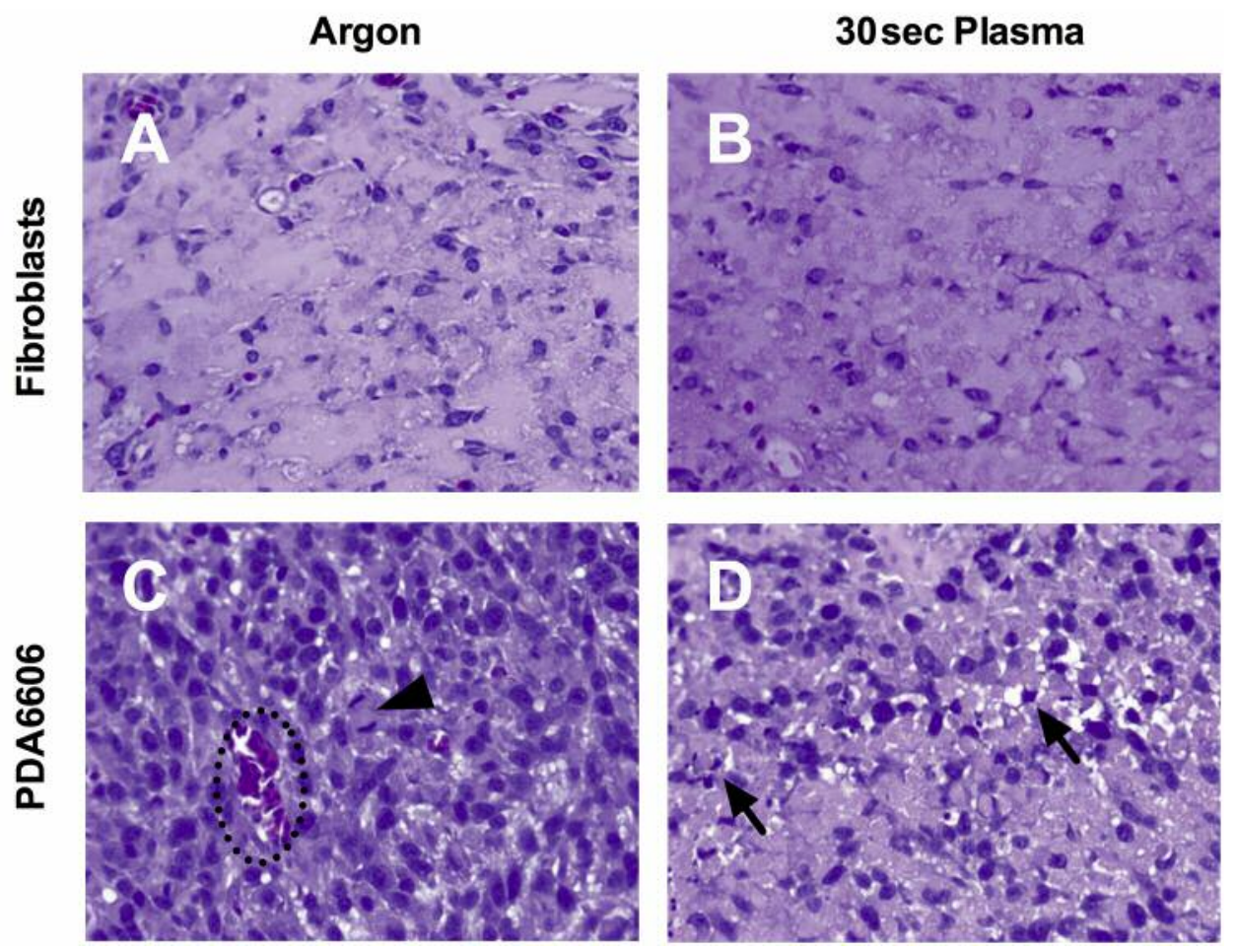

Figure 5. H\&E staining of solid spheres from pancreatic cancer cells and non-cancer spheres of murine fibroblasts. (A, B) showing spindle-shaped nuclei and bigger intercellular space in comparison to cancer cells $(C, D)$, murine fibroblast spheres grown on chicken embryos in ovo displayed no differences when comparing argon gas, mock treatment, (A) to $30 \mathrm{sec}$ of cold physical plasma treatment (B); (C) mock-treated, argon gas treated, cancer cells showed big cell nuclei, tightly stuck together causing small intercellular spaces, mitotic figures (arrowhead) and a strong vascularization (interrupted line), hallmarks of malignant tissue; (D) after 30 s exposure to cold physical plasma, pancreatic cancer tumors showed signs of cell death, as seen with generation of apoptotic bodies, pycnotic, dark small nuclei, and a drained cell organization with eosinophilic cytoplasm rests (arrows). Representative images are shown, original magnification 400x.

results using the clinically established ROS-scavenger NAC (55) suggested a main role of radical chemistry in cytotoxic effects. In principal, this accounts also for 3D cell spheres grown in vitro and in ovo that were not directly protected from a large liquid film and thus directly accessible to plasma-derived short-lived radical species.

Apart from plasma and liquid redox chemistry, our results clearly indicate a selective toxicity of plasma-derived reactive species towards malignant pancreatic tumor cells over non-malignant primary fibroblasts. This corroborates previous findings that demonstrated selective toxicity in tumor cells using cold physical plasma sources (56-61). There are different theories of how this selectivity is achieved with none of them being confirmed so far. One is the assumption that cancer cells have more aquaporins in their cell membrane (62). These water channels not only carry water in and out of cells but also facilitate the uptake of long-lived plasma-derived oxidants such as hydrogen peroxide (63). With dry argon as feed gas used in this study, our plasma jet produces only little hydrogen peroxide in the gas phase (64), suggesting that hydrogen peroxide is unlikely to have a significant contribution in our three-dimensional model cell spheres. Another theory claims a significance of membrane-bound catalase for plasma-derived reactivespecies dependent tumor cell kill (65). Specifically, this enzyme is claimed to protect tumor cells from autocrine hydrogen peroxide and peroxynitrite-mediated tumor cell apoptosis. Yet, the in vivo relevance of this mechanism remains to be established. A third hypothesis attributes a role to membrane-based cholesterol in dictating the selectivity of plasma-mediated toxicity in cancer versus non-cancerous cells (66). However, experimental evidence is missing to support this theory. A fourth theory is that of "oxidative balance" (67-69). It proposes that metabolic reprogramming in cancer cells (e.g. from oxidative phosphorylation in mitochondria to glycolysis) leads to higher endogenous ROS levels compared to that of non-malignant cells (70). This would make cancer cells more prone to ROS-induced cell death as with cold physical plasma treatment (71). However, our own data suggest that mitochondria remain an important 
target in cancer cells, also using cold physical plasmas (72). This is based on the general finding that some types of tumor cells employ both oxidative phosphorylation and glycolysis to meet their energy needs (73). Moreover, ROS not only damage cellular biomolecules but also serve as reactive agents in thiol-arrays responsible for redox-mediated signaling function (74). Yet, it remains to be explored which redox proteins are key switches in translating plasma-derived ROS into apoptotic responses in malignant over nonmalignant cells.

\section{Conflicts of Interest}

The Authors declare that they have no competing interests regarding this work.

\section{Acknowledgements}

The study was funded in part by the German Research Foundation (DFG, grant number Ev168/2 1). EF and SB received support by the German Federal Ministry of Education and Research (BMBF, grant number 03Z22DN11).

\section{References}

1 Ferlay J, Soerjomataram I, Dikshit R, Eser S, Mathers C, Rebelo M, Parkin DM, Forman D and Bray F: Cancer incidence and mortality worldwide: sources, methods and major patterns in GLOBOCAN 2012. Int J Cancer 136: E359-386, 2015.

2 Rahib L, Smith BD, Aizenberg R, Rosenzweig AB, Fleshman JM and Matrisian LM: Projecting cancer incidence and deaths to 2030: the unexpected burden of thyroid, liver, and pancreas cancers in the United States. Cancer Res 74: 2913-2921, 2014.

3 Soriano A, Castells A, Ayuso C, Ayuso JR, de Caralt MT, Gines MA, Real MI, Gilabert R, Quinto L, Trilla A, Feu F, Montanya $X$, Fernandez-Cruz L and Navarro S: Preoperative staging and tumor resectability assessment of pancreatic cancer: prospective study comparing endoscopic ultrasonography, helical computed tomography, magnetic resonance imaging, and angiography. Am J Gastroenterol 99: 492-501, 2004.

4 Alexakis N, Halloran C, Raraty M, Ghaneh P, Sutton R and Neoptolemos JP: Current standards of surgery for pancreatic cancer. Br J Surg 91: 1410-1427, 2004.

5 Winter JM, Cameron JL, Campbell KA, Arnold MA, Chang DC Coleman J, Hodgin MB, Sauter PK, Hruban RH, Riall TS, Schulick RD, Choti MA, Lillemoe KD and Yeo CJ: 1423 pancreaticoduodenectomies for pancreatic cancer: A singleinstitution experience. J Gastrointest Surg 10: 1199-1211, 2006.

6 Dunnbier M, Schmidt-Bleker A, Winter J, Wolfram M, Hippler $\mathrm{R}$, Weltmann KD and Reuter S: Ambient air particle transport into the effluent of a cold atmospheric-pressure argon plasma jet investigated by molecular beam mass spectrometry. J Phys D: Appl Phys 46: 435203, 2013.

7 Schmidt-Bleker A, Bansemer R, Reuter S and Weltmann KD: How to produce an NOx- instead of Ox-based chemistry with a cold atmospheric plasma jet. Plasma Process Polym 13: 11201127, 2016.
8 Winter J, Brandenburg R and Weltmann KD: Atmospheric pressure plasma jets: an overview of devices and new directions. Plasma Sources Sci T 24: 064001, 2015.

9 Ishaq M, Kumar S, Varinli H, Han ZJ, Rider AE, Evans MD, Murphy $\mathrm{AB}$ and Ostrikov $\mathrm{K}$ : Atmospheric gas plasma-induced ROS production activates TNF-ASK1 pathway for the induction of melanoma cancer cell apoptosis. Mol Biol Cell 25: 1523$1531,2014$.

10 Bekeschus S, Rodder K, Fregin B, Otto O, Lippert M, Weltmann KD, Wende K, Schmidt A and Gandhirajan RK: Toxicity and immunogenicity in murine melanoma following exposure to physical plasma-derived oxidants. Oxid Med Cell Longev 4396467: 1-12, 2017.

11 Schmidt A, Bekeschus S, von Woedtke T and Hasse S: Cell migration and adhesion of a human melanoma cell line is decreased by cold plasma treatment. Clin Plas Med 3: 24-31, 2015.

12 Tanaka H, Mizuno M, Ishikawa K, Nakamura K, Kajiyama H, Kano H, Kikkawa $\mathrm{F}$ and Hori M: Plasma-Activated Medium Selectively kills Glioblastoma Brain Tumor Cells by DownRegulating a Survival Signaling Molecule, AKT Kinase. Plasma Med 1: 265-277, 2011.

13 Chen Z, Simonyan H, Cheng X, Gjika E, Lin L, Canady J, Sherman JH, Young C and Keidar M: A novel micro cold atmospheric plasma device for glioblastoma both in vitro and in vivo. Cancers (Basel) 9: 61, 2017.

14 Cheng X, Sherman J, Murphy W, Ratovitski E, Canady J and Keidar M: The effect of tuning cold plasma composition on glioblastoma cell viability. PLoS One 9: e98652, 2014.

15 Schmidt A, Rodder K, Hasse S, Masur K, Toups L, Lillig CH, von Woedtke T, Wende $\mathrm{K}$ and Bekeschus S: Redox-regulation of activator protein 1 family members in blood cancer cell lines exposed to cold physical plasma-treated medium. Plasma Process Polym 13: 1179-1188, 2016.

16 Turrini E, Laurita R, Stancampiano A, Catanzaro E, Calcabrini C, Maffei F, Gherardi M, Colombo V and Fimognari C: Cold atmospheric plasma induces apoptosis and oxidative stress pathway regulation in T-lymphoblastoid leukemia cells. Oxid Med Cell Longev 2017: 4271065, 2017.

17 Bekeschus S, Wende K, Hefny MM, Rodder K, Jablonowski H, Schmidt A, Woedtke TV, Weltmann KD and Benedikt J: Oxygen atoms are critical in rendering THP-1 leukaemia cells susceptible to cold physical plasma-induced apoptosis. Sci Rep 7: 1-12, 2017.

18 Utsumi F, Kajiyama H, Nakamura K, Tanaka H, Mizuno M, Ishikawa K, Kondo H, Kano H, Hori M and Kikkawa F: Effect of indirect nonequilibrium atmospheric pressure plasma on anti-proliferative activity against chronic chemo-resistant ovarian cancer cells in vitro and in vivo. PLoS One 8: e81576, 2013.

19 Ishida C, Mori M, Nakamura K, Tanaka H, Mizuno M, Hori M, Iwase A, Kikkawa F and Toyokuni S: Non-thermal plasma prevents progression of endometriosis in mice. Free Radic Res 50: 1131-1139, 2016.

20 Koensgen D, Besic I, Gumbel D, Kaul A, Weiss M, Diesing K, Kramer A, Bekeschus S, Mustea A and Stope MB: Cold atmospheric plasma (CAP) and CAP-stimulated cell culture media suppress ovarian cancer cell growth - a putative treatment option in ovarian cancer therapy. Anticancer Res 37: 6739-6744, 2017. 
21 Weiss M, Gumbel D, Hanschmann EM, Mandelkow R, Gelbrich N, Zimmermann U, Walther R, Ekkernkamp A, Sckell A, Kramer A, Burchardt M, Lillig CH and Stope MB: Cold atmospheric plasma treatment induces anti-proliferative effects in prostate cancer cells by redox and apoptotic signaling pathways. PLoS One 10: e0130350, 2015.

22 Hirst AM, Simms MS, Mann VM, Maitland NJ, O'Connell D and Frame FM: Low-temperature plasma treatment induces DNA damage leading to necrotic cell death in primary prostate epithelial cells. Br J Cancer 112: 1536-1545, 2015.

23 Zhunussova A, Vitol EA, Polyak B, Tuleukhanov S, Brooks AD, Sensenig R, Friedman G and Orynbayeva Z: MitochondriaMediated Anticancer Effects of Non-Thermal Atmospheric Plasma. PLoS One 11: e0156818, 2016.

24 Tuhvatulin AI, Sysolyatina EV, Scheblyakov DV, Logunov DY, Vasiliev MM, Yurova MA, Danilova MA, Petrov OF, Naroditsky BS, Morfill GE, Grigoriev AI, Fortov VE, Gintsburg AL and Ermolaeva SA: Non-thermal plasma causes p53-dependent apoptosis in human colon carcinoma cells. Acta Naturae 4: 82-87, 2012.

25 Bekeschus S, Lin A, Fridman A, Wende K, Weltmann K-D and Miller V: A Comparison of Floating-Electrode DBD and kINPen Jet: Plasma parameters to achieve similar growth reduction in colon cancer cells under standardized conditions. Plasma Chem Plasma Process 38: 1-12, 2018.

26 Irani S, Shahmirani Z, Atyabi SM and Mirpoor S: Induction of growth arrest in colorectal cancer cells by cold plasma and gold nanoparticles. Arch Med Sci 11: 1286-1295, 2015.

27 Binenbaum Y, Ben-David G, Gil Z, Slutsker YZ, Ryzhkov MA, Felsteiner J, Krasik YE and Cohen JT: Cold atmospheric plasma, created at the tip of an elongated flexible capillary using low electric current, can slow the progression of melanoma. PLoS One 12: e0169457, 2017.

28 Brulle L, Vandamme M, Ries D, Martel E, Robert E, Lerondel S, Trichet V, Richard S, Pouvesle JM and Le Pape A: Effects of a non thermal plasma treatment alone or in combination with gemcitabine in a MIA PaCa2-luc orthotopic pancreatic carcinoma model. PLoS One 7: e52653, 2012.

29 Vandamme M, Robert E, Lerondel S, Sarron V, Ries D, Dozias S, Sobilo J, Gosset D, Kieda C, Legrain B, Pouvesle JM and Pape AL: ROS implication in a new antitumor strategy based on non-thermal plasma. Int J Cancer 130: 2185-2194, 2012.

30 Metelmann H-R, Nedrelow DS, Seebauer C, Schuster M, von Woedtke T, Weltmann K-D, Kindler S, Metelmann PH, Finkelstein SE, Von Hoff DD and Podmelle F: Head and neck cancer treatment and physical plasma. Clin Plas Med 3: 17-23, 2015.

31 Metelmann H-R, Seebauer C, Miller V, Fridman A, Bauer G, Graves DB, Pouvesle J-M, Rutkowski R, Schuster M, Bekeschus S, Wende K, Masur K, Hasse S, Gerling T, Hori M, Tanaka H, Ha Choi E, Weltmann K-D, Metelmann PH, Von Hoff DD and Woedtke Tv: Clinical experience with cold plasma in the treatment of locally advanced head and neck cancer. Clin Plas Med 9: 6-13, 2018.

32 Schuster M, Seebauer C, Rutkowski R, Hauschild A, Podmelle F, Metelmann C, Metelmann B, von Woedtke T, Hasse S, Weltmann KD and Metelmann HR: Visible tumor surface response to physical plasma and apoptotic cell kill in head and neck cancer. J Craniomaxillofac Surg 44: 1445-1452, 2016.

33 Kluge S, Bekeschus S, Bender C, Benkhai H, Sckell A, Below $\mathrm{H}$, Stope MB and Kramer A: Investigating the mutagenicity of a cold argon-plasma jet in an HET-MN model. PLoS One 11: 1$15,2016$.
34 Wende K, Bekeschus S, Schmidt A, Jatsch L, Hasse S, Weltmann KD, Masur K and von Woedtke T: Risk assessment of a cold argon plasma jet in respect to its mutagenicity. Mutat Res Genet Toxicol Environ Mutagen 798-799: 48-54, 2016.

35 Schmidt A, Woedtke TV, Stenzel J, Lindner T, Polei S, Vollmar $\mathrm{B}$ and Bekeschus S: One year follow-up risk assessment in SKH-1 mice and wounds treated with an argon plasma jet. Int J Mol Sci 18: pii: E868, 2017.

36 Partecke LI, Evert K, Haugk J, Doering F, Normann L, Diedrich S, Weiss FU, Evert M, Huebner NO, Guenther C, Heidecke CD, Kramer A, Bussiahn R, Weltmann KD, Pati O, Bender C and von Bernstorff W: Tissue tolerable plasma (TTP) induces apoptosis in pancreatic cancer cells in vitro and in vivo. BMC Cancer 12: 473, 2012.

37 Tuveson DA, Zhu L, Gopinathan A, Willis NA, Kachatrian L, Grochow R, Pin CL, Mitin NY, Taparowsky EJ, Gimotty PA, Hruban RH, Jacks $T$ and Konieczny SF: Mist1-KrasG12D knock-in mice develop mixed differentiation metastatic exocrine pancreatic carcinoma and hepatocellular carcinoma. Cancer Res 66: 242-247, 2006.

38 Jozefczuk J, Drews K and Adjaye J: Preparation of mouse embryonic fibroblast cells suitable for culturing human embryonic and induced pluripotent stem cells. J Vis Exp 64: pii: 3854, 2012.

39 Bekeschus S, Schmidt A, Weltmann K-D and von Woedtke T: The plasma jet kINPen - A powerful tool for wound healing. Clin Plas Med 4: 19-28, 2016.

40 Ahn HJ, Kim KI, Hoan NN, Kim CH, Moon E, Choi KS, Yang SS and Lee JS: Targeting cancer cells with reactive oxygen and nitrogen species generated by atmospheric-pressure air plasma. PLoS One 9: e86173, 2014.

41 Akhlaghi M, Rajaei H, Mashayekh AS, Shafiae M, Mahdikia H, Khani M, Hassan ZM and Shokri B: Determination of the optimum conditions for lung cancer cells treatment using cold atmospheric plasma. Phys Plasmas 23: 103512, 2016.

42 Canal C, Fontelo R, Hamouda I, Guillem-Marti J, Cvelbar U and Ginebra MP: Plasma-induced selectivity in bone cancer cells death. Free Radic Biol Med 110: 72-80, 2017.

43 Han D, Cho JH, Lee RH, Bang W, Park K, Kim MS, Shim JH, Chae JI and Moon SY: Antitumorigenic effect of atmosphericpressure dielectric barrier discharge on human colorectal cancer cells via regulation of Sp1 transcription factor. Sci Rep 7: 43081, 2017.

44 Hou J, Ma J, Yu KN, Li W, Cheng C, Bao L and Han W: Nonthermal plasma treatment altered gene expression profiling in nonsmall-cell lung cancer A549 cells. BMC Genomics 16: 435, 2015.

45 Ishaq M, Bazaka K and Ostrikov K: Pro-apoptotic NOXA is implicated in atmospheric-pressure plasma-induced melanoma cell death. J Phys D: Appl Phys 48: 464002, 2015.

46 Laroussi M: Interaction of cold plasmas with biological cells: What we have learned so far. Bull Am Phys Soc, 2006.

47 Jablonowski H, Bussiahn R, Hammer MU, Weltmann KD, von Woedtke $\mathrm{T}$ and Reuter S: Impact of plasma jet vacuum ultraviolet radiation on reactive oxygen species generation in bio-relevant liquids. Physics of Plasmas 22: 122008, 2015.

48 Bruggeman PJ, Kushner MJ, Locke BR, Gardeniers JGE, Graham WG, Graves DB, Hofman-Caris RCHM, Maric D, Reid JP, Ceriani E, Fernandez Rivas D, Foster JE, Garrick SC, Gorbanev Y, Hamaguchi S, Iza F, Jablonowski H, Klimova E, Kolb J, Krcma F, Lukes P, Machala Z, Marinov I, Mariotti D, 
Mededovic Thagard S, Minakata D, Neyts EC, Pawlat J, Petrovic ZL, Pflieger R, Reuter S, Schram DC, Schröter S, Shiraiwa M, Tarabová B, Tsai PA, Verlet JRR, von Woedtke T, Wilson KR, Yasui K and Zvereva G: Plasma-liquid interactions: a review and roadmap. Plasma Sources Sci T 25: 053002, 2016.

49 Gaborit G, Jarrige P, Lecoche F, Dahdah J, Duraz E, Volat C and Duvillaret L: Single Shot and Vectorial Characterization of Intense Electric Field in Various Environments With Pigtailed Electrooptic Probe. IEEE Trans Plasma Sci 42: 1265-1273, 2014.

50 Jablonowski $\mathrm{H}$ and von Woedtke $\mathrm{T}$ : Research on plasma medicine-relevant plasma-liquid interaction: What happened in the past five years? Clin Plas Med 3: 42-52, 2015.

51 Bekeschus S, Kolata J, Winterbourn C, Kramer A, Turner R, Weltmann KD, Broker B and Masur K: Hydrogen peroxide: A central player in physical plasma-induced oxidative stress in human blood cells. Free Radic Res 48: 542-549, 2014.

52 Bekeschus S, Mueller A, Miller V, Gaipl U and Weltmann KD: Physical plasma elicits immunogenic cancer cell death and mitochondrial singlet oxygen. IEEE Trans Radiat Plasma Med Sci 2: 138-146, 2018.

53 Bekeschus S, Schmidt A, Niessner F, Gerling T, Weltmann KD and Wende $\mathrm{K}$ : Basic research in plasma medicine - A throughput approach from liquids to cells. journal of visualized experiments: e56331, 2017.

54 Bekeschus S, Scherwietes L, Freund E, Liedtke KR, Hackbarth $\mathrm{C}$, von Woedtke $\mathrm{T}$ and Partecke LI: Plasma-treated medium tunes the inflammatory profile in murine bone marrow-derived macrophages. Clin Plas Med 11: 1-9, 2018.

55 Dodd S, Dean O, Copolov DL, Malhi GS and Berk M: Nacetylcysteine for antioxidant therapy: pharmacology and clinical utility. Expert Opin Biol Ther 8: 1955-1962, 2008.

56 Choi BBR, Choi JH, Hong JW, Song KW, Lee HJ, Kim UK and Kim GC: Selective killing of melanoma cells with non-thermal atmospheric pressure plasma and p-FAK antibody conjugated gold nanoparticles. Int J Med Sci 14: 1101-1109, 2017.

57 Duan J, Lu X and He G: The selective effect of plasma activated medium in an in vitro co-culture of liver cancer and normal cells. J Appl Phys 121: 013302, 2017.

58 Guerrero-Preston R, Ogawa T, Uemura M, Shumulinsky G, Valle BL, Pirini F, Ravi R, Sidransky D, Keidar M and Trink B: Cold atmospheric plasma treatment selectively targets head and neck squamous cell carcinoma cells. Int J Mol Med 34: 941-946, 2014.

59 Kim SJ and Chung TH: Cold atmospheric plasma jet-generated RONS and their selective effects on normal and carcinoma cells. Sci Rep 6: 20332, 2016.

$60 \mathrm{Kim}$ SJ, Joh HM and Chung TH: Production of intracellular reactive oxygen species and change of cell viability induced by atmospheric pressure plasma in normal and cancer cells. Appl Phys Lett 103: 153705, 2013.

61 Zucker SN, Zirnheld J, Bagati A, DiSanto TM, Des Soye B, Wawrzyniak JA, Etemadi K, Nikiforov M and Berezney R: Preferential induction of apoptotic cell death in melanoma cells as compared with normal keratinocytes using a non-thermal plasma torch. Cancer Biol Ther 13: 1299-1306, 2012.
62 Yan D, Sherman JH and Keidar M: Cold atmospheric plasma, a novel promising anti-cancer treatment modality. Oncotarget 8 : 15977-15995, 2017.

63 Almasalmeh A, Krenc D, Wu B and Beitz E: Structural determinants of the hydrogen peroxide permeability of aquaporins. FEBS J 281: 647-656, 2014.

64 Winter J, Wende K, Masur K, Iseni S, Dunnbier M, Hammer MU, Tresp H, Weltmann KD and Reuter S: Feed gas humidity: a vital parameter affecting a cold atmospheric-pressure plasma jet and plasma-treated human skin cells. J Phys D: Appl Phys 46: 295401, 2013.

65 Bauer G: Tumor cell-protective catalase as a novel target for rational therapeutic approaches based on specific intercellular ROS signaling. Anticancer Res 32: 2599-2624, 2012.

66 Van der Paal J, Verheyen C, Neyts EC and Bogaerts A: Hampering effect of cholesterol on the permeation of reactive oxygen species through phospholipids bilayer: possible explanation for plasma cancer selectivity. Sci Rep 7: 39526, 2017.

67 Birben E, Sahiner UM, Sackesen C, Erzurum S and Kalayci O: Oxidative stress and antioxidant defense. World Allergy Organ J 5: 9-19, 2012.

68 Glasauer A and Chandel NS: Targeting antioxidants for cancer therapy. Biochem Pharmacol 92: 90-101, 2014.

69 Gorrini C, Harris IS and Mak TW: Modulation of oxidative stress as an anticancer strategy. Nat Rev Drug Discov 12: 931947, 2013.

70 Ward PS and Thompson CB: Metabolic reprogramming: a cancer hallmark even warburg did not anticipate. Cancer Cell 21: 297-308, 2012.

71 Cui X: Reactive oxygen species: the achilles' heel of cancer cells? Antioxid Redox Signal 16: 1212-1214, 2012.

72 Gandhirajan R, Rödder K, Bodnar Y, Pasquale-Melo G, Emmert $\mathrm{S}$, Gruiger C, Weltmann $\mathrm{K}$ and Bekeschus S: Cytochrome C oxidase inhibition and cold plasma-derived oxidants synergize in melanoma cell death induction. Sci Rep 8: 12734, 2018.

73 Groß CJ, Mishra R, Schneider KS, Médard G, Wettmarshausen J, Dittlein D, Shi H, Gorka O, Koenig A, Fromm S, Magnani G, Cicovic T, Hartjes L, Smollich J, Robertson AAB, Cooper MA, Schmidt-Supprian M, Schuster M, Schroder K, Broz P, TraidlHoffmann C, Beutler B, Kuster B, Ruland J, Schneider S, Perocchi $\mathrm{F}$ and Groß O: K+ efflux-independent NLRP3 inflammasome activation by small molecules targeting mitochondria. Immunity 45: 761-773, 2016.

74 Lorenzen I, Mullen L, Bekeschus S and Hanschmann EM: Redox regulation of inflammatory processes is enzymatically controlled. Oxid Med Cell Longev 8459402: 1-23, 2017.
Received August 30, 2018

Revised September 20, 2018 Accepted September 24, 2018 